\title{
Decomposer biomass in the rhizosphere to assess rhizodeposition
}

\author{
Søren Christensen, Lisa Bjørnlund and Mette Vestergård
}

S. Christensen (schristensen@bi.ku.dk), L. Bjørnlund and M. Vestergaird, Dept Terrestrial Ecology, Copenhagen Univ., Øster Farimagsgade 2D, DK-1353 Copenhagen K, Denmark.

\begin{abstract}
Quantification of the organic carbon released from plant roots is a challenge. These compounds of rhizodeposition are quickly transformed into $\mathrm{CO}_{2}$ and eventually bacterial biomass to be consumed by bacterivores (protozoa and nematodes). Microbes stimulate rhizodeposition several-fold so assays under sterile conditions give an unrealistic value. Quantifying bacterial production from ${ }^{3} \mathrm{H}$-thymidine incorporation falls short in the rhizosphere and the use of isotopes does not allow clear distinction between labeled $\mathrm{CO}_{2}$ released from roots or microbes. We reduced rhizodeposition in 3-5 week old barley with a 2 week leaf aphid attack and found that biomass of bacterivores but not bacteria in the rhizosphere correlated with plant-induced respiration activity belowground. This indicated top-down control of the bacteria. Moreover, at increasing density of aphids, bacterivore biomass in the rhizosphere decreased to the level in soil unaffected by roots. This suggests that difference in bacterivore biomass directly reflects variations in rhizodeposition. Rhizodeposition is estimated from plant-induced increases in bacterial and bacterivore biomass, and yield factors, maintenance requirements, and turnover rates from the literature. We use literature values that maximize requirements for organic carbon and still estimate the total organic rhizodeposition to be as little as $4-6 \%$ of the plant-induced respiration belowground.
\end{abstract}

During the growing season annual crop plants transport up to $40 \%$ of the net primary production (NPP) to the roots (Lynch and Whipps 1990, Jensen 1993). Part of this carbon $(10-20 \%$ of NPP) can be utilised by the root symbionts AM and Rhizobium (Harris et al. 1985, Jakobsen and Rosendahl 1990, Smith and Read 1997), another fraction is deposited in the soil and consumed by the free-living rhizosphere organisms, and the remaining is used for growth and respiration of the root. Part of the rhizodeposition is root cap cells and mucigel important for root growth and contact to the surrounding soil (Schippers and Van Vuurde 1978), and the remaining fraction is soluble root exudates.

The root exudates are consumed with very high efficiency by the rhizosphere microbes and at the same time these consumers affect rhizodeposition markedly; rhizodeposition was 5-12 times higher from non-sterile compared to sterile roots in liquid culture (Barber and Lynch 1977) and similarly increased 3-34 times when microbes were introduced to soil, separated from the roots by a millipore membrane (Meharg and Killham 1995). The tight coupling between exudation and microbial growth is the major problem in analysing the activities in the rhizosphere. We are short of good methods for quantifying bacterial production in the rhizosphere. Incorporation of tritiated thymidine, originally intended as a production measurement for bacteria is currently used as an assay of activity (Söderberg and Bååth 1998) partly because of problems with establishing reliable conversion factors between incorporation of label and bacterial growth (Christensen 1993). Methods that employ carbon isotopes have been in operation for decades and are recently developed to give a detailed view of which soil microbes that grow on root exudates (Butler et al. 2003) but we do not know if the ${ }^{13} \mathrm{C}$ or ${ }^{14} \mathrm{C}$ labelled $\mathrm{CO}_{2}$ came directly from the root or was taken up by microbes as labelled organic matter from the root and subsequently released as microbially respired $\mathrm{CO}_{2}$. Recently Kuzyakóv (2002) employed four different 
isotopic approaches and suggested that $50-60 \%$ of the total plant-induced respiration was microbial (Kuzyakóv 2002). There is evidence for a tight coupling between carbon transport to the roots and the population size of the bacterivorous microfauna in the rhizosphere whereas no strong relation was demonstrated for the bacterial population (Rønn et al. 2002, Wamberg et al. 2003a, 2003b). This suggests a topdown regulation of bacterial biomass from bacterivorous organisms.

We earlier found that leaf-sucking aphids present for two weeks resulted in a decreased carbon export from the roots since plant-induced belowground respiration as well as rhizosphere bacteria, protozoa, and nematodes decreased when aphids were introduced to the leaves (Vestergård et al. 2004). Plant growth and uptake of $\mathrm{N}$ and $\mathrm{P}$ was unaffected by the herbivores (Vestergård et al. 2004) which suggests that brief aphid attacks reduced rhizodeposition without affecting plant growth and nutrient uptake markedly. Since respiration and bacterivore biomass was measured on different soil cores a firm correlation analysis of these measures was not possible in Vestergård et al. (2004).

In this experiment we want to clarify how belowground respiration and bacterivore biomass in the rhizosphere correlate, using our previous finding that plants subjected to brief aphid attacks reduce rhizodeposition. Based on this we will estimate the organic rhizodeposition as fraction of the plant-induced respiration belowground and compare the values with previous estimates based on results of isotopic methods.

\section{Material and methods}

\section{Preparation of pots for plant growth}

Clay loam soil was collected from a wheat field after harvest. The soil was air-dried sieved $(2 \mathrm{~mm})$ and mixed with quartz sand (1:1) and added fresh soil inoculum ( $6 \%$ by weight) from the same site. Soil portions of $1670 \mathrm{~g}$ DW were packed in plastic cores $(10 \mathrm{~cm}$ diameter) to $16 \mathrm{~cm}$ height. To the cores the following nutrients were added in solution $\left(\mathrm{mg} \mathrm{kg}^{-1}\right.$ soil $\left.\mathrm{DW}\right)$ : $\mathrm{NH}_{4} \mathrm{NO}_{3}$ (411), $\mathrm{KH}_{2} \mathrm{PO}_{4}$ (120), $\mathrm{Na}_{2} \mathrm{HPO}_{4}$ (2.3), $\mathrm{K}_{2} \mathrm{SO}_{4}(150), \mathrm{CuSO}_{4}(4.2), \mathrm{ZnSO}_{4}(10.8), \mathrm{MnSO}_{4}$ (21), $\mathrm{CoSO}_{4}(0.67), \mathrm{MgSO}_{4}(90), \mathrm{Na}_{2} \mathrm{MoO}_{4}(0.36)$, $\mathrm{CaCl}(150)$.

Two barley seeds (Hordeum vulgare cv. Scarlett) were planted in the cores that were placed in a growth chamber with $8 \mathrm{~h}$ at $860 \mu \mathrm{mol} \mathrm{m}{ }^{-2} \mathrm{~s}^{-1}$ and $355 \mu \mathrm{mol} \mathrm{m}^{-2} \mathrm{~s}^{-1}$ for $4 \mathrm{~h}$ before and after that which gives $16 \mathrm{~h}$ light and $8 \mathrm{~h}$ darkness. Chamber temperature was $20^{\circ} \mathrm{C}$ for $12 \mathrm{~h}$ centered at the time of highest light intensity and $15^{\circ} \mathrm{C}$ the remaining time. The seedlings were led out through a side hole in the upper end of the core. After nine days of plant growth the stems of the plants were mounted in Terostat-IX (Henkel $\mathrm{GmbH}$, Heidelberg, Germany) making a seal, which allows measurement of belowground respiration activity (below).

All planted cores were equipped with perforated plastic bags around the plants to prevent aphid migration between cores. On day 21 two specimen of the bird cherry-oat aphid (Rhopalosiphum padi) were placed on a leaf on each of the treated plants. Planted cores were held at $5-10 \%$ moisture (dry) or $10-15 \%$ moisture (wet) with or without aphids on the leaves giving four treatments with five replicates. There were additionally two unplanted cores for each of the two moisture contents.

\section{Plant-induced respiration belowground}

The headspace ( 0.51 air) above the soil of planted cores was sealed from the outside atmosphere under a lid and circulated with the aid of pumps via a gas chromatograph with TC detector to quantify $\mathrm{CO}_{2}$ accumulation. To avoid excessive changes in $\mathrm{O}_{2}$ and $\mathrm{CO}_{2}$ concentrations during one-day measurements, the recirculating air passed an extra tank giving a total of $7.5 \mathrm{l}$ air in the systems. At the start of incubation $30 \mathrm{ml} \mathrm{N} \mathrm{N}_{2} \mathrm{O}$ was supplied to each channel. The gas chromatograph analysed concentrations of $\mathrm{CO}_{2}, \mathrm{~N}_{2} \mathrm{O}$, and $\mathrm{N}_{2}+\mathrm{O}_{2}$ every second hour from the 24 cores and results were recorded on a computer. The $\mathrm{N}_{2}+\mathrm{O}_{2}$ (constituting more than $99 \%$ of the air volume) served as an internal standard to compensate for channel specific pressure differences in the gas sampling loop. A decrease in $\mathrm{N}_{2} \mathrm{O}$ concentration allowed channel specific compensation for leaks of the system. Excess $\mathrm{CO}_{2}$ and $\mathrm{N}_{2} \mathrm{O}$ leaked at similar rates in a preliminary test without soil (data not shown). Leaks normally amounted to $1-2 \%$ of the accumulated $\mathrm{CO}_{2}$ during the $2 \mathrm{~h}$ between measurements. The lids were left on the cores for $25 \mathrm{~h}$ allowing a cumulated diurnal respiration measurement that was performed every 2-3 days. Plant-induced respiration was calculated as the respiration in the single planted cores minus the average respiration from unplanted cores of the actual moisture content. Respiration rates in unplanted cores were about $15 \%$ of the activity in planted cores. The respiration rate at the last day of measurement was divided by amount of root $\mathrm{C}$ in the core to give specific root respiration.

\section{Plant analysis}

At harvest day 35, shoot and root biomass (DW) was recorded. Root carbon was calculated as $40 \%$ of the loss on ignition, determined at $500^{\circ} \mathrm{C}$ for $2 \mathrm{~h}$. Total $\mathrm{N}$ and $\mathrm{P}$ in plant material was determined on $0.1 \mathrm{~g}$ ground 
shoot material, digested in a mixture of sulphuric acid and selenious acid. Total $\mathrm{N}$ and $\mathrm{P}$ in the digest were determined using the indophenol and the molybdenum blue methods (Kedrowski 1983), respectively.

\section{Rhizosphere populations}

Rhizosphere soil was sampled by gently shaking the roots attached to the main plant and gathering pieces of roots with associated soil. The rhizosphere soil made up $45 \mathrm{~g}$ on average of the $1650 \mathrm{~g}$ soil in the cores.

Bacterial numbers were estimated as colony forming units (CFU) on agar ( $3 \mathrm{~g} \mathrm{l}^{-1}$ Tryptic Soy Broth, Difco) plates and counted after 9 days of incubation at $15^{\circ} \mathrm{C}$. Protozoa were determined with a modified version of the most rrobable number method (Darbyshire et al. 1974, Rønn et al. 1995). Nematodes were extracted for $48 \mathrm{~h}$ from a $10 \mathrm{~g}$ subsample of rhizosphere soil by a modified Baermann tray extraction method. Nematodes were counted immediately at $40 \times$ magnification and were then heat-fixed $\left(80^{\circ} \mathrm{C}\right)$ in $4 \%$ formaldehyde. In four of the five replicate samples 26-82 individuals (average 56) were subsequently identified to family or genus level according to Bongers (1988) at 400 and $1000 \times$ magnification, and assigned to feeding group according to Yeates et al. (1993).

\section{Statistics}

Effects of soil moisture level and aphids from day 21-36 on plant biomass and nutrient content, specific root respiration, and rhizosphere populations were tested by a two way ANOVA (SigmaStat version 2.03). Effects of soil moisture and aphids on plantinduced respiration were tested by a GLM procedure on Repeated Measurements using SAS for Windows, version 6.12. The GLM was run as a 1-way analysis up to day 21 and as a two-way analysis from day 2136. Correlations between plant-induced respiration, plant-induced microbivore biomass, and number of aphids per g shoot were tested with a Spearman Rank correlation analysis (SigmaStat version 2.03).

\section{Results and discussion}

\section{Plant growth}

The plant biomass was $1 / 3$ lower at low than at high soil moisture (Table 1) and plant-induced belowground respiration showed the same moisture response (Fig. 1) resulting in no effect of soil moisture on specific root respiration (Table 1) in accordance with the observation of Stewart and Metherell (1999) in grassland soil. The plant $\mathrm{N}$-uptake is estimated to $150 \mathrm{mg} \mathrm{N}$ at maximum (Table 1) corresponding to more than half of the $240 \mathrm{mg} \mathrm{N}$ added to the pots. The plants should therefore not be considered seriously $\mathrm{N}$ limited. Aphid presence did not affect plant biomass or plant $\mathrm{P}$ but plant $\mathrm{N}$ was slightly increased (Table 1). Plant-induced belowground respiration diminished with aphids in both moisture treatments (Fig. 1) in accordance with our previous experience (Vestergård et al. 2004). The effect of moisture on root respiration was apparent throughout, but the effect of aphids developed with plant age (Fig. 1). Since the aphids apparently reduced respiration earlier at the low soil moisture (Fig. 1) it is suggested that lower water availability propagated the aphid effect on respiration activity well in line with Riedell (1989) who found the plant response to an aphid attack to resemble a moisture stress for barley. Aphids tended to reduce specific root respiration (not significant, Table 1). It is remarkable that a carbon flow corresponding to $3-7 \%$ of the total root biomass $\mathrm{C}$ left the roots each day during this period (Table 1) giving a half-life of root carbon of only $10-23 \mathrm{~d}$. This is in accordance with Ostle et al. (2000) who showed a turnover of ${ }^{13} \mathrm{C}$ label in roots from day $1-7$ after labelling corresponding to $T_{1 / 2}=14 \mathrm{~d}$.

Table 1. Barley biomass and content of $\mathrm{N}$ and $\mathrm{P}$ after five weeks of plant growth. Rhizosphere respiration expressed per $\mathrm{g}$ root $\mathrm{C}$ was measured during the last two days of growth based on root biomass at harvest. Table shows average values and SE in parenthesis $(\mathrm{n}=5)$.

\begin{tabular}{|c|c|c|c|c|c|c|}
\hline $\begin{array}{l}\text { Soil moisture } \\
\left(\mathrm{g} 100 \mathrm{~g}^{-1}\right)\end{array}$ & Herbivores & $\begin{array}{l}\text { Aphids } \\
\text { (plant }^{-1} \text { ) }\end{array}$ & $\begin{array}{c}\text { Plant } \\
\text { biomass (g) }\end{array}$ & $\begin{array}{c}\text { Plant } N \\
\left(\mathrm{mg} \mathrm{g}^{-1} \text { shoot }\right)\end{array}$ & $\begin{array}{c}\text { Plant } P \\
\left(\mathrm{mg} \mathrm{g}^{-1} \text { shoot}\right)\end{array}$ & $\begin{array}{l}\text { Specific root respiration } \\
\left(\mathrm{mg} \mathrm{CO}_{2}-\mathrm{Cg}^{-1}\right. \\
\left.\text { root }-\mathrm{C} \text { day }^{-1}\right)\end{array}$ \\
\hline \multirow[t]{2}{*}{$5-10$} & control & & $2.57(0.23)$ & $40.9(1,0)$ & $3.83(0.22)$ & $65(12)$ \\
\hline & aphids & 235 (107) & $2.10(0.31)$ & $44.3(1,0)$ & $4.09(0.17)$ & $55(16)$ \\
\hline \multirow[t]{2}{*}{$10-15$} & control & & $3.44(0.26)$ & $41.7(1,0)$ & $3.14(0,18)$ & $58(8)$ \\
\hline & aphids & $160(110)$ & $3.55(0.39)$ & $43.6(1,1)$ & $3.25(0,21)$ & $34(8)$ \\
\hline P (aphids) & & - & 0.55 & 0.023 & 0.37 & 0.151 \\
\hline $\mathrm{P}$ (water $\times$ aphids) & & - & 0.35 & 0.4 & 0.7 & 0.56 \\
\hline
\end{tabular}




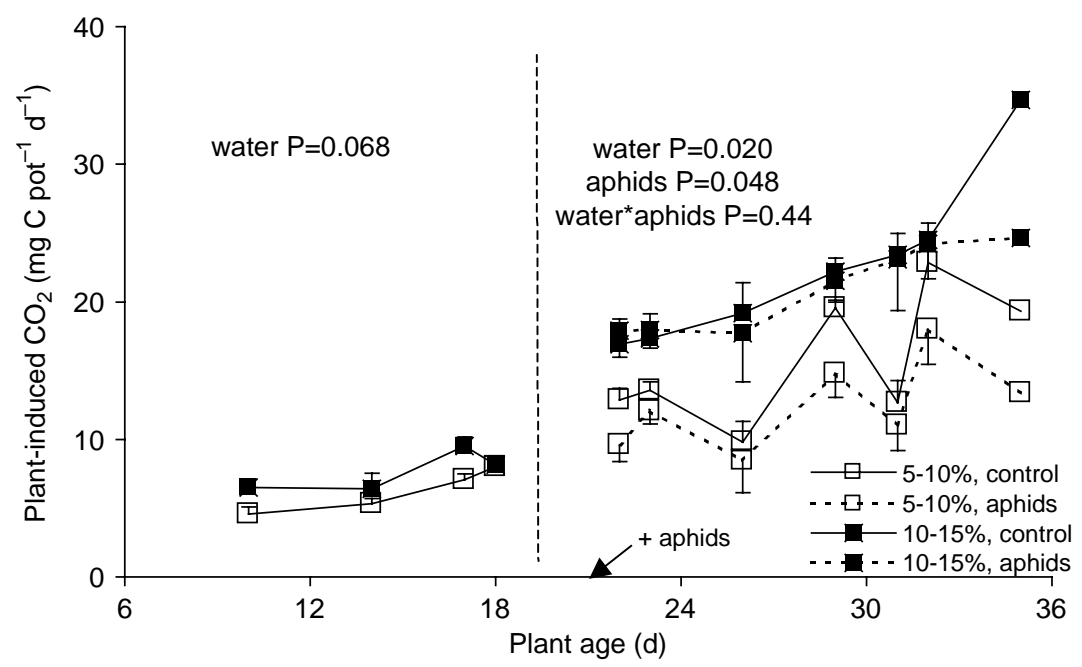

Fig. 1. Plant-induced respiration (planted cores minus unplanted cores) before and after aphid addition. Lines are average of five replicate cores and error bars are SE. Results of one-way and two-way ANOVA performed on data before and after addition of aphids, respectively.

\section{Rhizosphere organisms}

Number of bacteria in rhizosphere soil were 11 and 13 times above bulk soil values $\left(5.6-6.4 \times 10^{6} \mathrm{~g}^{-1}\right.$ soil) at low and high moisture, respectively, and $25 \%$ reduced at low compared to high moisture $(\mathrm{p}=0.027$, Table 2$)$. There was no effect of aphids on bacterial numbers. Protozoa showed a rhizosphere effect of 3 and 5 times higher numbers compared to bulk soil values (14 200$14300 \mathrm{~g}^{-1}$ soil) at low and high moisture, respectively. Protozoan numbers tended to decrease with aphids on the leaves $(\mathrm{p}=0.059$, Table 2$)$, which is similar to our previous experience (Vestergård et al. 2004) whereas moisture did not affect numbers significantly. There were 17 and 71 times more bacterial feeding nematodes in rhizosphere soil compared to bulk soil $\left(0.3-1.6 \mathrm{~g}^{-1}\right.$ soil) at low and higher moisture, respectively. The bacterial feeding nematodes reported constituted $86 \% \pm 0.6 \%$ of the total nematode number in the four treatments. The clear rhizosphere effect on soil bacteria, protozoa, and nematodes is in accordance with earlier reports including the larger rhizosphere effect on nematodes than on protozoa (Griffiths et al. 1992). Number of bacterial feeding nematodes were strongly reduced at low soil moisture (Table 2) and the decrease was more pronounced in Rhabditidae than in Cephalobidae (data not shown), which is in compliance with Griffiths et al. (1995). Aphids did not affect nematode numbers (Table 2).

The cumulated biomass of bacterivorous protozoa and nematodes induced by the roots correlated positively with the root-induced belowground $\mathrm{CO}_{2}$ production on the last day before harvest (Fig. 2). The relation was robust across all moisture and aphid treatments. In contrast, root-induced bacteria were not correlated to root-induced belowground $\mathrm{CO}_{2}$ production (Fig. 2). We therefore suggest that bacterivores as opposed to bacteria qualitatively reflects the total plant-induced belowground activity indicating a strong top-down regulation of bacteria by their grazers in accordance with the conclusions on the rhizosphere environment in the reviews of Wardle (2002) and Bonkowski (2004).

Table 2. Number of bacteria and bacterivorous protozoa and nematodes in the rhizosphere after five weeks of plant growth. Table shows average values and SE in parenthesis $(n=5)$.

\begin{tabular}{llccc}
\hline $\begin{array}{l}\text { Soil moisture } \\
\left(\mathrm{g} 100 \mathrm{~g}^{-1}\right)\end{array}$ & Herbivores & \multicolumn{3}{c}{ No. $\mathrm{g}^{-1}$ rhizosphere soil } \\
\cline { 3 - 5 } & & Bacteria & Protozoa & Bacterivorous nematodes \\
\hline $5-10$ & control & $62.8(7.9) 10^{6}$ & $42.300(11.100)$ & $17.3(7,1)$ \\
& aphids & $62.7(6.1) 10^{6}$ & $28.900(8.360)$ & $17.6(7,0)$ \\
$10-15$ & Control & $83.7(7.9) 10^{6}$ & $68.500(18.500)$ & $80.3(10,6)$ \\
& aphids & $82.3(10.7) 10^{6}$ & $31.000(9.500)$ & $67.4(13,8)$ \\
P (water) & & 0.027 & 0.27 & 0.001 \\
(aphids) & & 0.9 & 0.059 & 0.52 \\
P (water $\times$ aphids) & & 0.9 & 0.34 & 0.54 \\
\hline
\end{tabular}




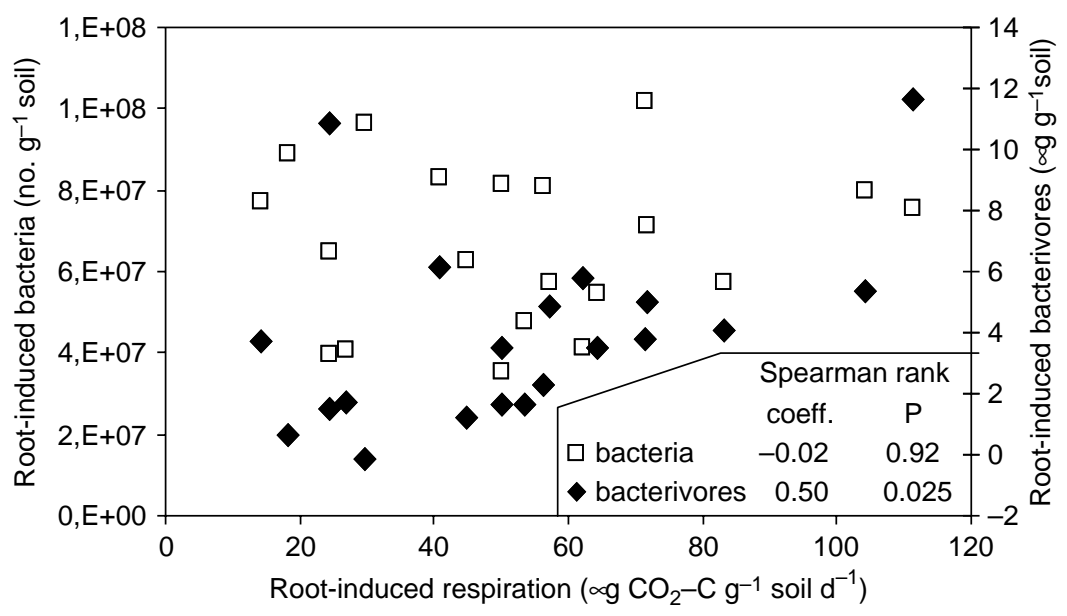

Fig. 2. Root-induced bacteria and root-induced bacterivore biomass in correlation with root-induced belowground respiration activity the day before harvest. Twenty data points (four treatments, five replicates) are shown.

\section{Herbivore effects}

Aphids mediated a larger $\mathrm{N}$ concentration in the plant without affecting its biomass (Table 1). This suggests a luxury consumption of $\mathrm{N}$ by the plant when belowground immobilisation in rhizosphere organisms is reduced at reduced rhizodeposition.

Aphid development was very variable on the plants (Table 1) ranging from 20 to 600 per g plant shoot in the aphid treatments with no difference between moisture levels. This variability may be due to differences in physiological status of the aphids introduced as well as genetic differences in the barley seeds used. Because of this variability in aphid growth, herbivore densities and soil parameters were related at the level of individual cores. Root-induced belowground respiration correlated negatively to aphid density showing a decrease with increasing aphid density to a level of $33-50 \%$ of the respiration activity without aphids (Fig. 3A). Although number of nematodes as opposed to protozoa was not affected by aphids the combined biomass of these bacterivores correlated negatively to aphid density (Fig. 3B). Furthermore it approached zero, i.e. the bacterivore biomass found in bulk soil without plants, as aphid density increased. Protozoa and bacterivorous nematodes dominated rootinduced bacterivore biomass in equal shares of rhizosphere samples (Fig. 3B).

The decrease in bacterivore biomass to bulk soil values at increasing aphid densities suggests that exudation of organic carbon from the roots is inhibited at increasing aphid attacks while plant growth was not affected (Fig. 3C).

\section{Carbon budget}

We want to estimate the release of organic $\mathrm{C}$ from the roots ((1)-(3) below) in relation to the total respiration induced by the plant ((4) below). Release of organic C from roots is the sum of carbon flows to (1) produce the rhizosphere bacteria under top-down control from bacterivores, (2) produce remaining rhizosphere bacteria not under predation control, and (3) bacterial maintenance requirements.

\section{(1) Production of bacteria under top-down control from bacterivores}

The average biomass of plant-induced bacterivores with no aphids present $\left(6.2 \mu \mathrm{g} \mathrm{g}^{-1}\right.$ rhizosphere soil, Fig. 3B) is converted to units of carbon $\left(2.8 \mu \mathrm{g} \mathrm{C} \mathrm{g} \mathrm{g}^{-1}\right.$ rhizosphere soil, Table 3). The bacterivore biomass is distributed on protozoa $\left(2.0 \mu \mathrm{g} \mathrm{C} \mathrm{g}^{-1}\right.$ rhizosphere soil) and nematodes $\left(0.8 \mu \mathrm{g} \mathrm{C} \mathrm{g}{ }^{-1}\right.$ rhizosphere soil), based on numbers (Table 2) and literature values on biovolume of the organisms (Ref. 1-3, Table 3). Using biovolumes for flagellates and amoebae of 50 and $400 \mu^{3}$, respectively, (Ref. 1; Stout and Heal 1967) we are certain not to underestimate protozoan biomass since a large fraction of the soil population will consist of individuals smaller than these (Ekelund and Rønn 1994). Likewise, the size of bacterivorous nematodes of $0.031 \mu^{3}$ (Ref. 3; Sohlenius and Sandor 1987) is higher than the $0.020 \mu \mathrm{m}^{3}$ usually encountered in our laboratory (Georgieva et al. 2005).

Literature values of production efficiencies (growth yields) are introduced to estimate the bacterial respiration that supports production of protozoa $\left(3.0 \mu \mathrm{g} \mathrm{C} \mathrm{g}^{-1}\right.$ 


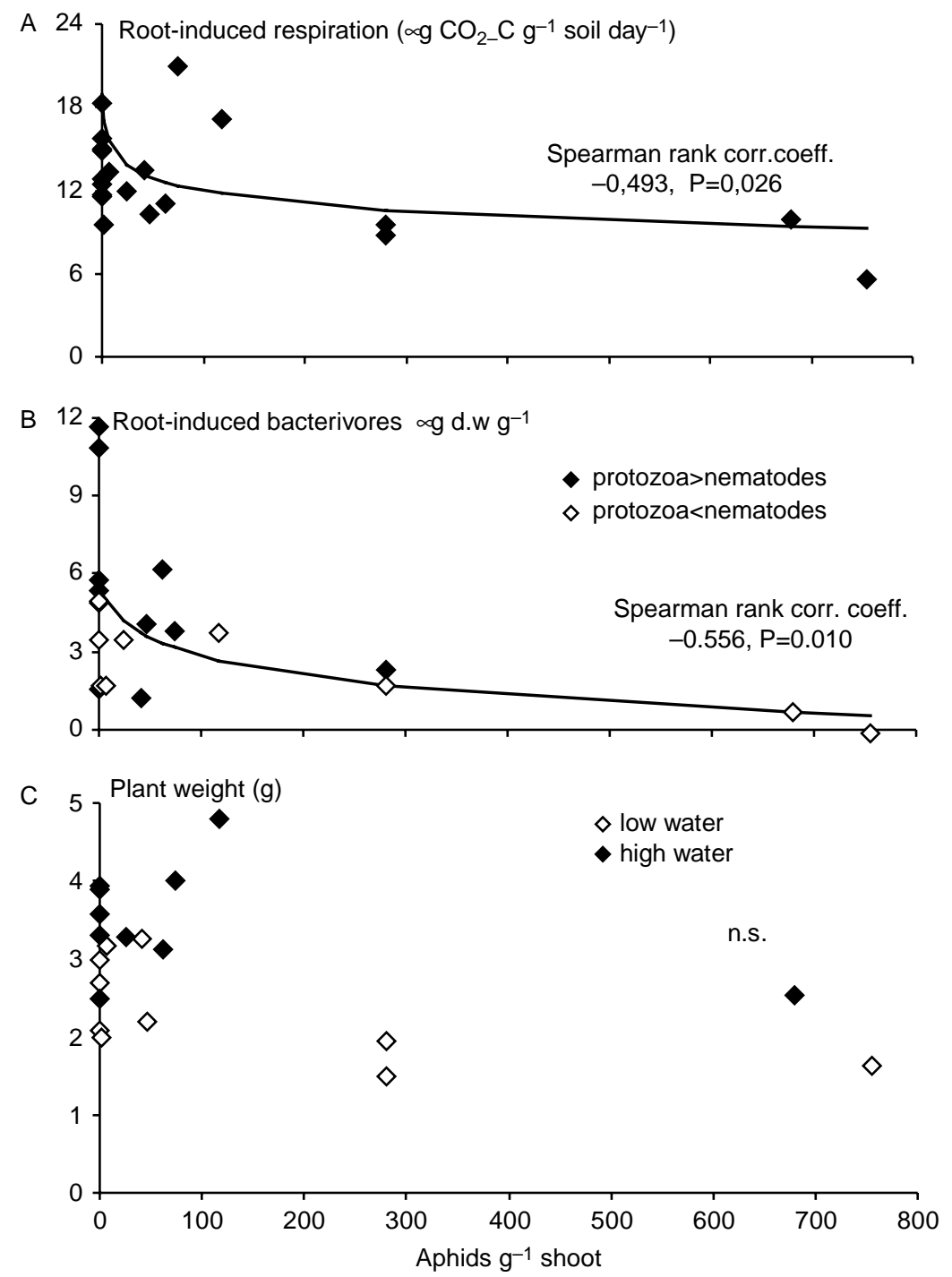

Fig. 3. (A) root-induced respiration, (B) root-induced bacterivores (protozoa plus nematodes), and (C) plant biomass; all plotted against aphid density on the plant shoots. The correlation analyses were performed on the data from all treatments taken together $(n=20)$. Data on bacterivore biomass $(B)$ are labeled white when nematodes dominated biomass and black when protozoa dominated biomass. Plant biomasses are labeled white for plants grown at low moisture and black for plants grown at high moisture. Correlation lines on (A) and (B) both have the formula $y=-a \times \ln (x)+b$.

rhizosphere soil) and nematodes (19.2 $\mu \mathrm{g} \mathrm{C} \mathrm{g}^{-1}$ rhizosphere soil). The production of bacteria requires root exudates amounting to $15.0+60.0=75 \mu \mathrm{g} \mathrm{C} \mathrm{g}^{-1}$ rhizosphere soil, to feed protozoa and nematodes, respectively (Table 3). The turnover rate of soil protozoa reviewed by Zwart et al. (1994) ranged between 0.02 and $0.16 \mathrm{~d}^{-1}$. We use the highest value of $0.16 \mathrm{~d}^{-1}$ for protozoan as well as nematode biomass to avoid underestimation of carbon requirement to maintain bacterivores. This gives 2.2 generations of bacterivores during the two weeks where bacterivores were inhibited by aphids corresponding to a total consumption of root exudates of $2.2 \times 75.0=168 \mu \mathrm{g}$ $\mathrm{C} \mathrm{g}^{-1}$ rhizosphere soil. This value is converted from a per gram rhizosphere soil to a per plant basis, giving $7.1 \mathrm{mg} \mathrm{C}$ core $^{-1}$.

\section{(2) Production of remaining bacteria}

The carbon budget should include any bacterial growth induced by the plant and possibly not recorded in the plate counts employed in this study. In a similar study the total bacterial number determined with acridine orange staining was 100 times above the plate count but 
the rhizosphere effect on these bacteria was only a nonsignificant $50 \%$ increase compared to the 8.3 -fold increase in plate countable bacteria in the rhizosphere (Christensen et al. 1992). This numeric increase in total bacterial biomass of $115-81.2=33.8 \mu \mathrm{g} \mathrm{C} \mathrm{g}^{-1}$ soil (rhizosphere soil minus bulk soil, Christensen et al. 1992) is included in the carbon budget. With a yield coefficient of 0.33 the total carbon consumption to produce these bacteria is $0.1 \mathrm{mg} \mathrm{C} \mathrm{g}^{-1}$ rhizosphere soil or $4.3 \mathrm{mg} \mathrm{C}$ core $^{-1}$ (Table 3).

\section{(3) Energy expenditure for maintenance processes}

To account for all consumption of organic carbon from rhizosphere bacteria maintenance requirements should be considered. The maintenance turnover for the soil bacterium Arthrobacter globiformis at a growth rate of $0.01 \mathrm{~h}^{-1}$ was $0.0008 \mathrm{~h}^{-1}$ (Chapman and Gray 1986) corresponding to 0.29 during 15 days. If we assume that the total bacterial biomass calculated above was present throughout the whole 2 -week period, the maintenance requirement is $0.29 \times 33.8=9.7 \mu \mathrm{g}$ biomass-C g ${ }^{-1}$ soil $15 \mathrm{~d}^{-1}$ or $9.7 / 0.33=29.5 \mu \mathrm{g}$ root exudate- $\mathrm{C} \mathrm{g}^{-1}$ soil $15 \mathrm{~d}^{-1}$. For the whole soil core this corresponds to $1.2 \mathrm{mg} \mathrm{C}$ core $^{-1}$ (Table 3).

Miscellaneous flows of organic carbon, not considered Root symbionts (AM fungi) were not studied on the plants in this study but these fungi were not important in a previous study at similar conditions (Vestergård et al. 2004). Bacterivores such as mites are not considered important. The establishment of microarthropods is delayed following drying and sieving of the soil and mites were not observed in the soil.

If carnivores on protozoa and nematodes were important we would expect carnivorous nematodes to be abundant but these were only observed occasionally.

\section{(4) Plant-induced respiration}

The plant-induced respiration activity belowground during the period when aphids were present (day 2135, Fig. 1) was 221 or $334 \mathrm{mg} \mathrm{C}$ core $^{-1}$ for dry or wet soil, respectively (Table 3 ).

\section{(5) Budget}

We may now calculate the total flow of organic plant carbon from the roots on basis of bacterial and bacterivore growth plus microbial maintenance requirements, or $7.1+4.3+1.2=12.6 \mathrm{mg} \mathrm{C}$ core $^{-1}$. This organic rhizodeposition, assayed from microbial and microbivore growth only constitutes $4-6 \%$ of the total respiration belowground of 221 or $334 \mathrm{mg} \mathrm{C}$ plant $^{-1}$ (Table 3). It should be emphasized that even though we used conversion factors from biomass to carbon requirement for soil heterotrophs that maximise the associated respiratory output (sections (1) - (3) above) this heterotrophic respiration only constitutes below $10 \%$ of the plant-induced respiration belowground. The major fraction of plant-induced respiration belowground was therefore due to root activity.

\section{Comparison with literature}

Pool dilution of ${ }^{14} \mathrm{C}$-labelled rhizodeposition from plants grown with ${ }^{14} \mathrm{CO}_{2}$ in unlabelled glucose (Cheng et al. 1993) directly aim at identifying microbial and root respiration. This technique suggested that 59$63 \%$ of the plant-induced respiration was microbial (Cheng et al. 1993, Kuzyakóv 2002), i.e. a much higher value than found in the present work. The technique of Cheng et al. (1993) employs huge glucose additions resulting in concentrations of $2000 \mu \mathrm{g} \mathrm{C} \mathrm{g}^{-1}$ soil corresponding roughly to $8000 \mu \mathrm{g} \mathrm{C} \mathrm{ml}^{-1}$ soil water with the soil moisture employed (Kuzyakóv 2002). Sugar is mainly exuded at the root tip in cereals (Semenov et al. 1999, Darwent et al. 2003) where the total concentration of sugars can be $20 \mu$ mole sucrose $\mathrm{g}^{-1}$ root fresh weight (Walter et al. 2003). This corresponds to roughly $25 \mu$ mole sucrose $\mathrm{ml}^{-1}$ root liquid, or $3600 \mu \mathrm{g} \mathrm{C} \mathrm{ml}^{-1}$ root liquid i.e. below half the concentration of added sugar in soil liquid in Kuzyakóv (2002). Since release of sugars from plant cells is a passive process the above estimate may suggest that root respiration could be underestimated in Kuzyakóv (2002) due to an inverted sugar gradient from the soil into the roots. Thereby roots could respire added ${ }^{12} \mathrm{C}$ glucose on top of the plant-derived ${ }^{14} \mathrm{C}$ sugar.

Indirect evidence for respiration by roots and by microorganisms feeding on root exudates is obtained from a pulse labelling experiment with ${ }^{13} \mathrm{CO}_{2}$ (Ostle et al. 2003). A large flow of ${ }^{13} \mathrm{CO}_{2}$ belowground within two days of labelling is ascribed to root respiration. A much smaller peak of respired ${ }^{13} \mathrm{CO}_{2}, 6$ days after labelling occurred simultaneously with an increase in C-13 labelled bacterial RNA in the soil thereby suggesting that the latter activity stems from microbial respiration on root exudates (Ostle et al. 2003). In an estimate based on these data, microbial activity amounts to $15-20 \%$ of total carbon release from the plant.

Still another pulse labelling experiment with ${ }^{13} \mathrm{C}$ found a maximum of $1.3-1.5 \%$ of the plant absorbed ${ }^{13} \mathrm{C}$ in microbial biomass about half of this already the day after labelling (Rangel-Castro et al. 2005). The paper does not report belowground respiration but we expect microbial activity to constitute an even smaller fraction of total carbon release from the plant compared to the result of Ostle et al. (2003) mentioned above. 
Table 3. Calculation of carbon transfer to grow the bacterivores observed. See text for explanation of calculations.

\begin{tabular}{|c|c|c|c|c|c|}
\hline & \multirow{2}{*}{$\begin{array}{l}{\text { Biomass } g^{-1}} \\
\text { rhizosphere soil }\end{array}$} & \multicolumn{2}{|c|}{$\mu \mathrm{g} \mathrm{C} \mathrm{g}^{-1}$ rhizosphere soil } & \multirow{2}{*}{$\operatorname{mgre}^{-1}$} & \\
\hline & & Protozoa & Nematodes & & \\
\hline \multicolumn{6}{|c|}{ (1) C-Flow to grow rhizosphere bacterai under top-down control } \\
\hline \multirow[t]{3}{*}{ Rhizosphere effect on nematodes and protozoa } & $6.2 \mu \mathrm{g}$ DW & & & & from Fig. $3 b$ \\
\hline & $2.8 \mu \mathrm{g} \mathrm{C}$ & & & & $45 \% \mathrm{C}$ in dry matter \\
\hline & & 2.0 & 0.8 & & From our data and ref. 1, 2, and 3 below \\
\hline \multicolumn{2}{|l|}{$\begin{array}{l}\text { Respiration during production of bacterivores } \\
\text { from bacteria }\end{array}$} & 3.0 & 19.2 & & $\begin{array}{l}\text { Production efficiencies } 0.4 \text { and } 0.04 \text { for proto-zoa and } \\
\text { nematodes, respectively (Coleman et al. 1987) }\end{array}$ \\
\hline \multicolumn{2}{|l|}{$\begin{array}{l}\text { Carbon flow during production of bacteria } \\
\text { consumed by bacterivores }\end{array}$} & 15.0 & 60.0 & & Production efficiency 0.33 for bacteria \\
\hline \multirow{3}{*}{$\begin{array}{l}\text { Flow of carbon via bacteria to produce } \\
\text { bacterivores observed }\end{array}$} & & & & & Sum of row above \\
\hline & & & & & $\begin{array}{l}\text { Bacterivore turnover rate } 0.16 \mathrm{~d}^{-1} \text { for } 14 \mathrm{~d} \\
\text { (Zwart et al. 1994) }\end{array}$ \\
\hline & & & & 7.1 & Average amount of rhizosphere soil $42.5 \mathrm{~g}$ \\
\hline \multicolumn{6}{|c|}{ (2) Respiration to grow remaining rhizosphere bacteria } \\
\hline \multirow{3}{*}{$\begin{array}{l}\text { Rhizosphere effect on total bacterial biomass } \\
\text { Carbon flow during production of total bacteria }\end{array}$} & $33.8 \mu \mathrm{g} \mathrm{C}$ & & & & Acridine orange direct counts (Christensen et al. 1992) \\
\hline & & & & & Production efficiency 0.33 for bacteria \\
\hline & & & & 4.3 & Average amount of rhizosphere soil $42.5 \mathrm{~g}$ \\
\hline \multicolumn{6}{|l|}{ (3) Maintenance requirement of rhizopshere bacterai } \\
\hline Maintenance requirement of total bacteria & $33.8 \mu \mathrm{g} \mathrm{C}$ & & & 1.2 & $\begin{array}{l}\text { Maintenance coeffi-cient } 0.0008 \mathrm{~h}^{-1} \text { (Chap-man } \\
\text { and Gray 1986) during } 15 \text { days }\end{array}$ \\
\hline \multicolumn{6}{|c|}{$(1)+(2)+(3)$ Organic carbon to grow and maintain rhizosphere organisms } \\
\hline \multicolumn{4}{|c|}{$\begin{array}{l}\text { Total flow of organic root carbon to bacteria } \\
\text { and bacterivores }\end{array}$} & 12.6 & Sum of (1), (2), and (3) above \\
\hline \multicolumn{6}{|l|}{ (4) Plant-induced respiration belowground } \\
\hline \multirow{2}{*}{$\begin{array}{l}\text { (Plant-induced root respiration when aphids } \\
\text { were absent }\end{array}$} & Dry soil & & & 221 & From Fig. 1, integrated over day $21-36$ \\
\hline & Wet soil & & & 334 & \\
\hline \multicolumn{6}{|c|}{ (5) Bacterial + faunal activity as fraction of plant-induced respiration } \\
\hline \multirow{2}{*}{$\begin{array}{l}5=(1+2+3) / 4 . \text { Organic root exudates as } \\
\text { frac-tion of plant-induced root resp. }\end{array}$} & Dry soil & & & $6.0 \%$ & Root exudates flow to bacterivores divided by \\
\hline & Wet soil & & & $4.0 \%$ & plant-induced repiration \\
\hline
\end{tabular}

Ref 1: Flagellate and amoebae biovolume 50 and $200 \mu \mathrm{l}$, respectively (Stout and Heal 1967), dry matter 20\%, and $45 \%$ C in dry matter

Ref 2: Proportion flagellates: amoebae $=4: 1$ in fertilized barley at 5 weeks age (Griffiths 1990)

Ref 3: Biomass of bacterivorous nematodes $0.031 \mu \mathrm{g}$ (Sohlenius and Sandor 1987) and 45\% C in DM 
It is the challenge for future work to reveal if microbial respiration constitutes more than half (Kuzyakóv 2002), one fifth (Ostle et al. 2003), or only a few percent (Rangel-Castro et al. 2005, the present work) of the total carbon introduced belowground by the plant.

Acknowledgements - The Villum Kann Rasmussen Foundation is acknowledged for supporting this work through the CLIMATE project. Annette Spangenberg performed the chemical analyses and helped with enumerating the populations.

\section{References}

Barber, D. A. and Lynch, J. M. 1977. Microbial growth in the rhizosphere. - Soil Biol. Biochem. 9: 305-308.

Bongers, T. 1988. De nematoden van Nederland. - Natuurhistorische Bibliotheek van de KNNV nr 46. Pirola, Schroorl, the Netherlands.

Bonkowski, M. 2004. Protozoa and plant growth: the microbial loop in soil revisited. - New Phytol. 162: 617-631.

Butler, J. L., Williams, M. A., Bottomley, P. J. et al. 2003. Microbial community dynamics associated with rhizosphere carbon flow. - Appl. Environ. Microbiol. 69: 6793-6800.

Chapman, S. J. and Gray, T. R. G. 1986. Improtance of cryptic growth, yield factors and maintenance energy in models of microbial growth in soil. - Soil Biol. Biochem. 18: $1-4$.

Cheng, W., Coleman, D. C., Carroll, C. R. et al. 1993. In situ measurement of root respiration and soiluble $\mathrm{C}$ concentrations in the rhizosphere. - Soil Biol. Biochem. 25: 1189-1196.

Christensen, H., Griffiths, B. and Christensen, S. 1992. Bacterial incorporation of tritiated thymidine and populations of bacteriophagous fauna in the rhizosphere of wheat. - Soil Biol. Biochem. 24: 703-709.

Christensen, H. 1993. Conversion factors for the thymidine incorporation technique estimated with bacteria in pure culture and on seedling roots. - Soil Biol. Biochem. 25: 1085-1096.

Darbyshire, J. F., Wheatley, R. E., Greaves, M. P. et al. 1974. Rapid micromethod for estimating bacterial and protozoan populations in soil, Rev.D. - Ecol. Biol. Sol 11: $465-475$.

Darwent, M. J., Paterson, E., McDonald, A. J. S. et al. 2003. Biosensor reporting of root exudation from Hordeum vulgare in relation to shoot nitrate concentration. - J. Exp. Bot. 54: 325-334.

Ekelund, F. and Rønn, R. 1994. Notes on protozoa in agricultural soil with emphasis on heterotrophic flagellates and naked amoebae and their ecology. - FEMS Microbiol. Rev. 15: 321-353.

Georgieva, S., Christensen, S. and Andersen, K. 2005. Nematode succession and microfauna-microorganism interactions during plant residue decomposition. - Soil Biol. Biochem. 37.
Griffiths, B. S. 1990. A comparison of microbial-feeding nematodes and protozoa in the rhizosphere of different plants. - Biol. Fertility Soils 9: 83-88.

Griffiths, B. S., Welschen, R., Arendonk, J. J. C. et al. 1992. The effect of nitrate-nitrogen supply on bacteria and bacteria-feeding fauna in the rhizosphere of different grass species. - Oecologia 91: 253-259.

Griffiths, B. S., Young, I. M. and Caul, S. 1995. Nematode and protozoan population-dynamics on decomposing barley leaves incubated at different soil matric potentials. - Pedobiologia 39: 454-461.

Harris, D., Pacovsky, R. S. and Paul, E. A. 1985. Carbon economy of soybean-rhizobium-glomus associations. - New Phytol. 101: 427-440.

Jakobsen, I. and Rosendahl, L. 1990. Carbon flow into soil and external hyphae from roots of mycorrhizal cucumber plants. - New Phytol. 115: 77-83.

Jensen, B. 1993. Rhizodeposition by ${ }^{14} \mathrm{CO}_{2}$-pulse-labelled spring barley grown in small field plots on sandy loam. - Soil Biol. Biochem. 11: 1553-1559.

Kedrowski, R. A. 1983. Extraction and analysis of nitrogen, phosphorus, and carbon fractions in plant material. - J. Plant Nutrition 6: 989-1011.

Kuzyakóv, Y. 2002. Separating microbial respiration of exudates from root respiration in non-sterile soil: a comparison of four methods. - Soil Biol. Biochem. 34: $1621-1631$.

Lynch, J. M. and Whipps, J. M. 1990. Substrate flow in the rhizosphere. - Plant Soil 129: 1-10.

Meharg, A. A. and Killham, K. 1995. Loss of exudates from the roots of perennial ryegrass inoculated with a range of microorganisms. - Plant Soil 170: 345-349.

Ostle, N., Ineson, P., Benham, D. et al. 2000. Carbon assimilation and turnover in grassland vegetation using an in situ ${ }^{13} \mathrm{CO}_{2}$ pulse labeling system. - Rapid Comm. Mass Spectrom. 14: 1345-1350.

Ostle, N., Whiteley, A. S., Bailey, M. J. et al. 2003. Active microbial RNA turnover in a grassland soil estimated using a ${ }^{13} \mathrm{CO}_{2}$ spike. - Soil Biol. Biochem. 35: 877-885.

Rangel-Castro, J. I., Prosser, J. I., Ostle, N. et al. 2005. Flux and turnover of fixed carbon in soil microbial biomass of limed and unlimed plots of an upland grassland ecosystem. - Environ. Microbiol. 7: 544-552.

Riedell, W. E. 1989. Effects of Russian wheat aphid infestation on barley plant plant response to drought stress. - Physiol. Plant. 77: 587-592.

Rønn, R., Ekelund, F. and Christensen, S. 1995. Optimizing soil extract and broth media for MPN-enumeration of naked amoebae and heterotrophic flagellates in soil. - Pedobiologia 39: 10-19.

Rønn, R., Gavito, M., Jakobsen, I. et al. 2002. Response of free-living soil protozoa to elevated atmospheric CO2 and presence of mycorrhiza. - Soil Biol. Biochem. 34: 923932.

Schippers, B. and Van Vuurde, J. W. L. 1978. Studies on microbial colonisation of wheat roots and the manipulation of the rhizosphere. - In: Loutit, M. W. and Miles, J. A. R. (eds), Microbial ecology 7. Springer, pp. 295-298.

Semenov, A. M., van Bruggen, A. H. C. and Zelenev, V. V. 1999. Moving waves of bacterial populations and total 
organic carbon along roots of wheat. - Microbial Ecol. 37: $116-128$.

Smith, S. E. and Read, D. J. 1997. Mycorrhizal symbiosis, 2nd ed.. - Academic Press.

Söderberg, K. H. and Bååth, E. 1998. Bacterial activity along a young barley root measured by the thymidine and leucine incorporation techniques. - Soil Biol. Biochem. 30: $1259-1268$.

Sohlenius, B. and Sandor, A. 1987. Vertical distribution of nematodes in arable soil under grass (Festuca pratensis) and barley (Hordeum vulgare). - Biol. Fertility Soils 3: 19-25.

Stewart, D. P. C. and Metherell, A. K. 1999. Carbon $\left({ }^{13} \mathrm{C}\right)$ uptake and allocation in pasture plants following field pulse labeling. - Plant Soil 210: 61-73.

Stout, J. D. and Heal, O. W. 1967. Protozoa. - In: Burges, A. and Raw, F. (eds), Soil biology. Academic Press, pp. $149-195$.

Vestergård, M., Bjørnlund, L. and Christensen, S. 2004. Aphid effects on rhizosphere microorganisms and microfauna depend more on barley growth phase than on soil fertilization. - Oecologia 141: 84-93.
Walter, A., Feil, R. and Schurr, U. 2003. Expansion dynamics, metabolite composition and substance transfer of the primary root growth zone of Zea mays L. grown in different external nutrient availabilities. - Plant Cell Environ. 26: 1451-1466.

Wamberg, C., Christensen, S. and Jakobsen, I. 2003a. Interaction between foliar-feeding insects, mycorrhizal fungi, and rhizosphere protozoa on pea plants. - Pedobiologia 47: 281-287.

Wamberg, C., Christensen, S., Jakobsen, I. et al. 2003b. The mycorrhizal fungus (Glomus intraradices) affects microbial activity in the rhizosphere of pea plants (Pisum sativum). - Soil Biol. Biochem. 35: 1351-1359.

Wardle, D. 2002. Communities and ecosystems. Linking aboveground and belowground components. - Princeton Univ. Press.

Yeates, G. W., Bongers, T., de Goede, R. G. M. et al. 1993. Feeding habits in soil nematode families and genera-an outline for soil ecologists. - J. Nematol. 25: 315-331.

Zwart, K. B., Kuikman, P. J. and Van Veen, J. A. 1994. Rhizosphere Protozoa: their significance in nutrient dynamics. - In: Darbyshire, J. F. (ed.), Soil Protozoa. CAB Int. 